\title{
NOTES ON THE WATER SHREW IN BOG HABITATS OF SOUTHEASTERN MANITOBA
}

by Charles H. Buckner and David G. H. Ray, Canadian Department of

Forestry and Rural Development, 25 Dafoe Road, Winnipeg 19

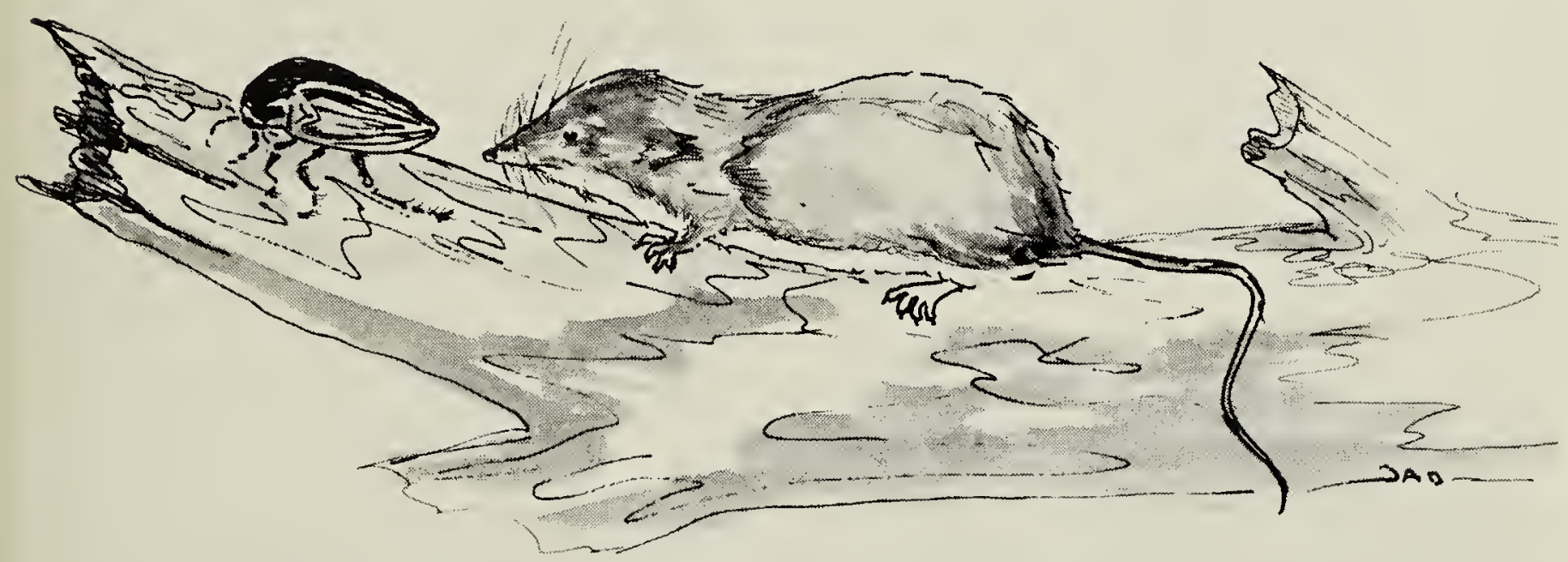

Water Shrew

Sketch by James A. Drouin

Although the usual habitat requirements of the Water Shrew, Sorex palustris palustris Richardson, include the edges of streams, the species is also an infrequent resident of sphagnum bog areas that may be a great distance from open water, exclusive of surface puddles (Buckner, 1966. Populations and ecological relationships of shrews in tamarack bogs of southeastern Manitoba. J. Mamm., $47: 181-194)$. During some 16 years of population studies on bog-dwelling shrews, information on the home range of the Water Shrew was obtained from two individuals encountered in live traps. Seven additional specimens captured in snap-back traps provided data on feeding habits in this habitat.

The specimens reported herein were collected in tamarack bog sites in the Whiteshell Provincial Park in eastern Manitoba. All sites were treed with tamarack, Larix laricina ( Du Roi) K. Koch, about 30-50 feet high. There was a thick mat of sphagnum moss on the floor, and ground cover was comprised chiefly of Labrador tea, Ledum groenlandicum Oeder, and dwarf birch, Betula glandulosa Michx. All sites were at least one-half mile from the shores of a lake or stream.

The traps, whether for taking specimens alive or dead, were set at intervals of one chain (66 feet) in a grid fashion. Live traps were of the pitfall type and consisted of clean one-quart oil cans. These were set in the evening and examined at two-hour intervals throughout the hours of darkness. Traps for collecting dead specimens were commercial snap-back mousetraps, and were set in the morning and examined daily.

The first Water Shrew captured alive was taken and released, after being marked by toe-clipping), on a plot one and one-half miles south of Red Rock Lake. In all it was captured seven times in five different traps, between August 18 and August 27, 1955: its trap-revealed home range was 0.8 acres. The second live-trapped individual was captured near Darwin. It was captured four times in four different traps between September 22 and September 29, 1966: its traprevealed home range was 0.5 acres. These are the first measurements of 


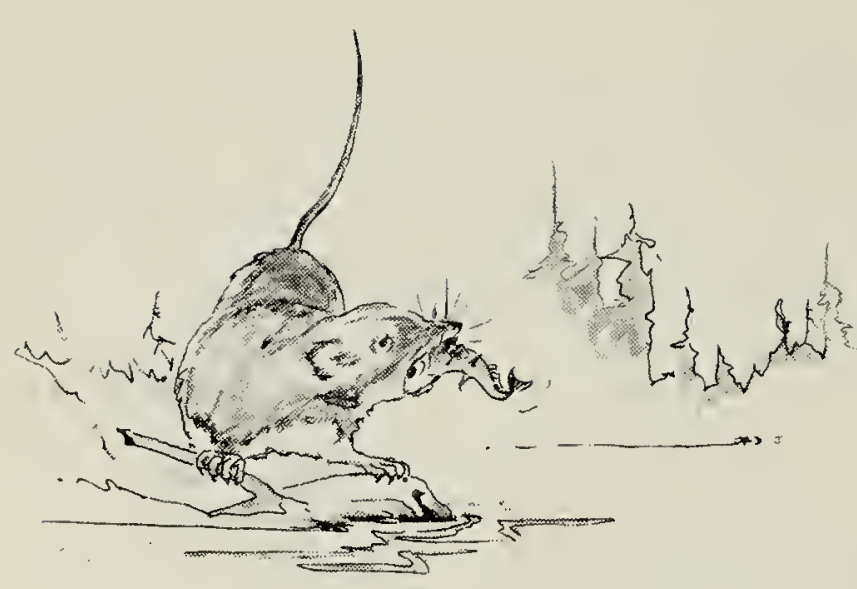

home range for this species so far as we are aware. Home ranges of the other long-tailed shrews in these areas are considerably more extensive, almost double in most cases, and the range of the Short-tailed Shrew in this habitat is some 30 per cent greater (Buckner, op. cit.).

Because the usual diet of the Water Shrew consists largely of small fishes and aquatic insects, and because in these restricted ranges fishes were unavailable and the supply of aquatic insects severely restricted, it was important to determine the feeding habits of the species under these con- ditions. The stomach contents of the seven specimens taken in snap-back traps were examined, and it was found that the largest single food class in every case was ground beetles (Carabidae). These insects formed about 30 per cent of the diet of the Water Shrew under these circumstances, and one individual had fed exclusively upon them. Next in importance was hymenopterous larvae and pupae, and third, lepidopterous pupae. Of minor importance were snails, Diptera, Arachnida, Odonata and Plecoptera. Thus is appears that the Water Shrew can behave as an opportunistic predator when the circumstances so demand.

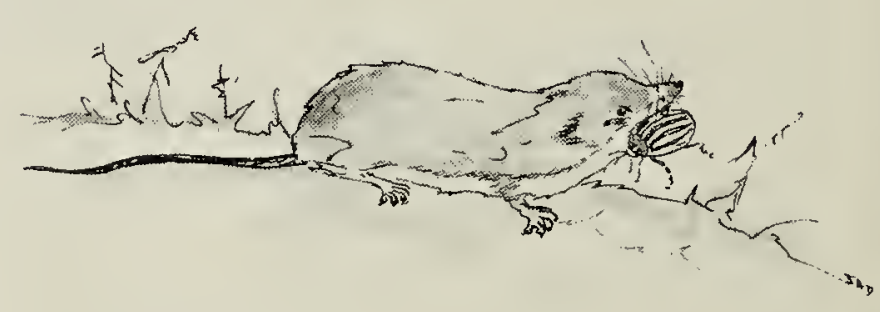

Water Shrew

Sketches by James A. Drouin

\title{
SHORT-TAILED SHREW IN NEST-BOX AT WEST SHOAL LAKE, MANITOBA
}

\author{
by Herbert W. R. Copland, Manitoba Museum of Man and Nature, \\ Winnipeg
}

A line of nest-boxes (20 at present) has been maintained for a few years at West Shoal Lake, north of Woodlands, Manitoba, by a small group of members of the Natural History Society of Manitoba, Winnipeg. The nest-boxes are positioned on trees close to the edge of long, narrow and intermittent bluffs of deciduous trees and shrubs along a low sandy ridge which is a former lake beach. The ridge is roughly parallel to and about 200 yards from the southwestern side of the lake. Primarily we were inter- ested in encouraging Eastern Bluebirds to nest, as they had been recorded in adjacent areas on a few occasions. No bluebirds have occupied any of the boxes to date but Tree Swallows and House Wrens have been using them.

On April 26, 1964, while cleaning out the boxes prior to the approaching nesting season, a mummified shrew was discovered in box No. 11. This box is mounted on a white poplar, the height of the entrance hole above ground level being seven feet. 